\title{
Potential of floating solar technology in Malaysia
}

\author{
Mohd Alif Saifuddin Jamalludin'1, Firdaus Muhammad-Sukki², Siti Hawa Abu-Bakar, \\ Fadzliana Ramlee ${ }^{4}$, Abu Bakar Munir ${ }^{5}$, Nurul Aini Bani ${ }^{6}$, Mohd Nabil Muhtazaruddin ${ }^{7}$, \\ Abdullahi Abubakar Mas'ud ${ }^{8}$, Jorge Alfredo Ardila-Rey ${ }^{9}$, Ahmad Syahrir Ayub $^{10}$, Nazmi Sellami ${ }^{11}$ \\ ${ }^{1}$ Aflex Ships Equipment Sdn Bhd, Malaysia \\ 2,10,11 School of Engineering, Robert Gordon University, United Kingdom \\ ${ }^{3}$ Universiti Kuala Lumpur British Malaysian Institute, Malaysia \\ ${ }^{4}$ Aerospace Research \& Science Division, School of Engineering, University of Glasgow, United Kingdom \\ ${ }^{5}$ Faculty of Law, University of Malaya, Malaysia \\ ${ }^{6,7}$ UTM Razak School of Engineering and Advanced Technology, Universiti Teknologi Malaysia, Malaysia \\ ${ }^{8}$ Department of Electrical and Electronics Engineering, Jubail Industrial College, Saudi Arabia \\ ${ }^{9}$ Department of Electrical Engineering, Universidad Técnica Federico Santa María, Chile
}

\section{Article Info}

Article history:

Received Aug 27, 2018

Revised Feb 23, 2019

Accepted Mar 6, 2019

\section{Keywords:}

Solar energy

Solar photovoltaic

Floating Solar

\begin{abstract}
Solar energy is a natural source of energy and is tremendously abundant. The concept of floating solar is to fulfil and to support the existing energy supply in order to enhance the human life. The floating solar exploits the massive availability of ocean region and the severe unavailability of land. The main purpose of this paper is to evaluate the potential of floating solar to be deployed in coastal or infield in Malaysia. It was predicted that such system could generate around 14,530 MWh per annum in Malaysia. It can be concluded that floating solar could be one of the most important ocean structures in the future because it is reliable, flexible and has virtually low cost production comparing with other ocean structures.
\end{abstract}

Copyright (C) 2019 Institute of Advanced Engineering and Science. All rights reserved.

\section{Corresponding Author:}

Mohd Alif Saifuddin Jamalludin, Aflex Ships Equipment Sdn Bhd,

8, Jalan Canggih 4, Taman Perindustrian Cemerlang, 81800 Ulu Tiram, Johor, Malaysia

Email: mohd.alif.saifuddin@gmail.com

\section{INTRODUCTION}

Power and energy sources are very important to human life and others. In fact, the world is practically ground without energy. Industries would discontinue running and this circumstances will affect the global economy as well. Currently fossil fuel is a major source of the energy and it is used in many products [1-3]. Fossil fuel is becoming even more significant because it will soon become uncommon demand will exceed supply. To cope with the future energy demand within the environmental constraints, there is a requirement to go for renewable energy [4-9]. One abundant renewable energy resource that could be aggressively harnessed for energy production is solar energy [10,11]. Solar radiation is distributed over the entire planet and based on the survey; almost $44 \%$ of the world's population live within 150 kilometres of the coast and fresh water resources [12]. Relating these facts as truly sustainable resources, peoples will demands a fresh solution about the energy for life. The new concept of a large scale "Floating Solar" or "Solar Island" will brings this vision a step closer to reality.

The concept of a "Floating Offshore Solar Field" or "Solar Island" could be categorized under very large floating structures (VLFS), or also known as very large floating platforms (VLFP). This concept has been discussed in detail by Wang and Tay [13]. The floating structure should provide a very large surface area and it can be built by combining the floating units together to form an array. The floating structure has to 
comply with strength requirements, safety and meet at least the minimum operating conditions [14].To meet the safety requirement, the floating structure must have motions of less than those allowed. As a rule of thumb, VLFS is moored at one particular location for a long time and require minimum of maintenance $[14,15]$.

On the sea, the VLFS can be viewed as artificially man-made floating land; some even visualise this as static massive plates on the surface of the sea [13]. At the moment, there are two common configurations of VLFS; the semisubmersible-type and the pontoon-type [16]. The former is raised above the sea level using column tubes or ballast structural elements which keeps the effect of waves to the minimum while keeping a constant buoyancy force making it more suitable for installation in high seas with large waves [16]. The latter is static floating structure which is more suitable for installations in calm waters such as near the shoreline, inside a lagoon or a cove [16]. The existing VLFSs include: (i) the Mega-Float (Floating Airport), Tokyo Bay; (ii) Floating island on Han River; (iii) Floating performance stage, Marina Bay Singapore, and (iv) Floating oil storage, Kamigoto Island [13].

According to Wang and Tay [13], the advantage of building VLFS is that the structure is more ecofriendly due to the fact that there is minimal or no damage occur to the marine eco-system, they do not block deep harbours or causes any disruption on the sea currents. Moreover, it is quick and easy to construct, i.e. the parts can be constructed at different shipyards before being assembled at the desired location. This also means that any expansion and decommissioning of such structure can be easily carried out in the future due to its modularity. There are various shapes of VLFS to be considered which could reduce the hydroelastic responses.

To stabilise and optimise such system during its operation, a special anti-motion device or mooring system is needed, which consists of anchor and connectors and is connected to the floating structure by a mooring line [15-18]. The catenary mooring system is the most commonly used for installation in shallow water, the catenary mooring system is used.

The aim of this paper is to investigate the potential of floating solar technology to be deployed in coastal or infield in Malaysia. To the authors' knowledge, such analysis has never been explored before. This is explored by proposing a hexagonal design of a floating solar (discussed in Section 2) installed theoretically in 6 locations in Malaysia. A numerical calculations is then carried out to determine the potential output from such system.

\section{FLOATING SOLAR}

\subsection{Overview}

Generally floating solar is identified as a very large floating solar structure (VLFSS). Floating solar is a structure developed and deployed on the water surfaces to generate power [19-21]. In this paper, the target location is shoreline which is near to the human population. The configuration of floating solar consist a few major components; for example the main design shape (any shapes), solar array, floatation foam to afloat the solar array, pre-wired unit to minimize the electrical connection during installation, power cable and the power house. Moreover this structure will be moored directly to the seabed by suitable type of mooring line.

In this paper, hexagonal shape is chosen based on the superior potential of solar energy to be produced. Furthermore, the excellent solar array to be utilised is a thin-film technology which is lighter and flexible due to the insignificant thickness. The solar array types and selection will be discussed more in solar cell section.

Besides the floatation foam is highly important to support the buoyancy of the solar array [22]. Because of that the potential foam which is complied with the requirement criteria is a cross-linked closed cell foam. This foam technology already exist and apparently used as a floating map. Another important component in the VLFSS is the mooring line. Essentially the mooring line is a selected line connected between the floating solar and the anchor [17]. The function of this mooring line is to secure and tie the structure from drifting away from exact location.

The main advantages to construct the floating solar include [19-21]:

- Abundant natural energy sources.

- The oceans provide ample zone to energy demand

- Low operating and maintenance costs

- Solar panels supports by the buoyancy characteristic and allowing a simple structure.

- Air and seawater cooling promote higher efficiencies

- Cost effective to manufacture and environmentally friendly 


\subsection{Solar cells}

Photovoltaic (PV) is one of the most rapidly growing power generation technologies besides wind $[10,11]$. Silicone is one of the selected materials to be utilised in PV technology [23]. Silicone is a natural source of choice because of its low production cost, stable efficiencies, naturally abundant and nontoxicity [24]. However nowadays, the thin film technology also tremendously high potential in solar industry [24].

The most effective and common solar cell is crystalline silicone [10,23]. Crystalline silicone solar cells are usually thin-film, about $0.3 \mathrm{~mm}$ thick, sawn from silicone ingot [24]. Crystalline silicone thin film presents an encouraging concept of combining the benefit of conventional solar wafer-based technology and thin-film solar cell technology. Crystalline silicone was divided into two types which is mono- crystalline silicone and multi/poly crystalline silicone [11].

Gallium Arsenide (GaAs) thin films is categorized under III/V solar cells type [25]. This technology comprise a number of very fascinating benefits compared to cells on a substrate. GaAs thin films can be mounted on any flat or curved material. The thickness of the p-type GaAs layer was varied between $0.25 \mu \mathrm{m}$ and $2.5 \mu \mathrm{m}$ [26]. The comparison of these three solar cell technologies are presented in Table 1 while the module efficiency are indicated in Table 2.

The three solar array types in Table 2 are the most potential module to be used as a solar panel. However, GaAs thin film is selected as solar array for this project because most of the criteria complied and highly suitable to be utilised as well.

Table 1. Comparison of selected solar cell. Adapted from [26-28].

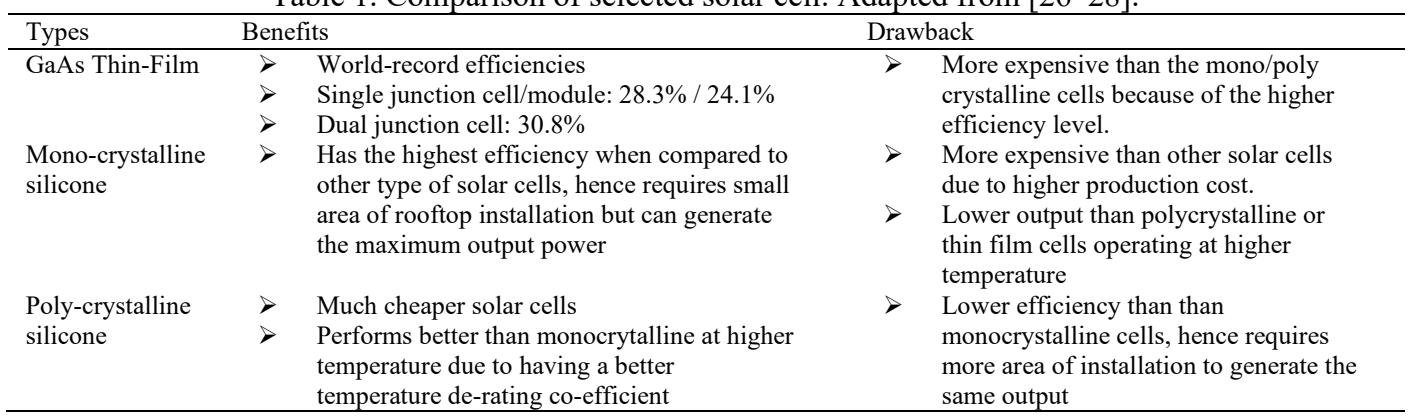

Table 2. Efficiency of selected solar cell. Adapted from [26].

\begin{tabular}{ccc}
\hline Module Technologies & Module Efficiency $(\%)$ & Thickness \\
\hline GaAs Thin-Film & $24.1-30.8$ & $0.25 \mu \mathrm{m}$ and $2: 5 \mu \mathrm{m}$ \\
$\begin{array}{c}\text { Mono-crystalline silicone } \\
\text { Multi/Poly-crystalline } \\
\text { silicone }\end{array}$ & $12.5-15$ & $0.3 \mathrm{~mm}$ \\
\hline
\end{tabular}

\subsection{Floatation foam - cross-linked closed cell foam}

The cross linked closed cell foam is widely used in marine industry and in this case, the flotation foam is made from the technology of cross-linked closed cell known as floating mat. The most significant advantages are the durability, flexibility and reliability of this material to be implemented on the water.

The concept is to attach the selected thin solar array on the pliable floatation mat together with prewired electrical connection (see Figure 1). The floatation foam is only absorbing insignificant quantities of liquid because of its closed cell structure. The lightweight characteristics of the thin film will not give an effect to the performance of the floatation foam.

The advantages of using the floatation foam by cross-linked closed cell are listed as follow.

- $\quad$ Unlimited patterns and easy customize into any shape or size.

- Virtually unsinkable and it is easy to assemble to other parts.

- The material characteristic; it is light, durable, safe and provides superior stability.

- $\quad$ Environmentally friendly and suitable for fresh water and sea water.

Int J Pow Elec \& Dri Syst, Vol. 10, No. 3, Sep 2019 : $1638-1644$ 


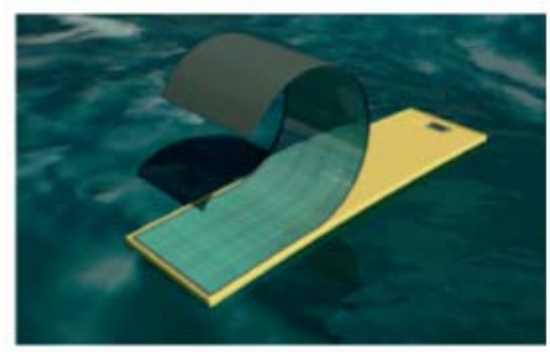

Figure 1. Solar array attached with floating mat

\subsection{Concept Design - Hexagonal Prototype Shape}

Hexagonal Prototype Shape design was identified as a potential design to be used as a floating solar. The structure area and the solar panel covered area can be computed by using the modelling process such as Autocad Drawing and Orcina Orcaflex software. Based on the calculation using Mathcad software, the total area of hexagonal shape is $8661.746 \mathrm{~m}^{2}$. By assuming $10 \%$ reduction due to certain conditions, the result of solar panel covered area (hexagonal) is $6,889.99 \mathrm{~m}^{2}$ and round up as $6,890 \mathrm{~m}^{2}$. Figure 2 shows the 3D hexagonal prototype shape.

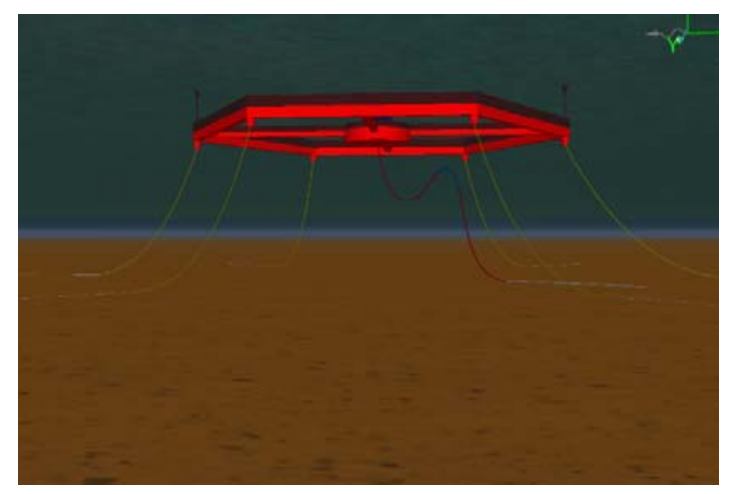

Figure 2.3D view - hexagonal shape

The hexagon design is technically known as a wave friendly design. Also, the result of the calculation shown that the hexagonal shape is extremely effective compared to circular shape due to the higher value or the solar panel covered area. The solar panel covered area of hexagonal shape is $15 \%$ larger than circular shape. Furthermore the assembly process is quite easy for hexagonal shape instead of circular shape because of the bending characteristic.

The $10 \%$ reduction in the calculation is because of the unknown area losses, e.g. for example the installation of pre-wired component and the installation of the floating mat. It should have a certain amount of gap between solar panel (attached with floating mat) with the pontoon to evade the collision. However the reduction percentage is only an initial indicator and should be modified for the real installation if necessary and safe.

\section{METHODOLOGY}

As indicated earlier, a numerical calculation is carried out to determine the output from VLFSS. Several parameters need to be identified. The first one is the location of installation plays a major role to it. The climate in Southeast Asia is generally tropical-hot and moist yearly with ample precipitation. This region has a wet and dry season affected by seasonal change in winds or monsoon. During the monsoon period it will cause an additional rainfall in most of the places, i.e. occurrences of thunderstorms and usually heavy rains within a short time. However, during the dry season the climate is hot and sunny. In South East Asia, solar energy has been acknowledged as having the utmost potential renewable energy resources as this 
region receives abundant sunlight all year long. The selected country in South East Asia is Malaysia and there are 6 specific locations that were identified as a good potential location to deploy the VLFSS. The locations are shown in Figure 3 while their specific position are presented in Table 3.

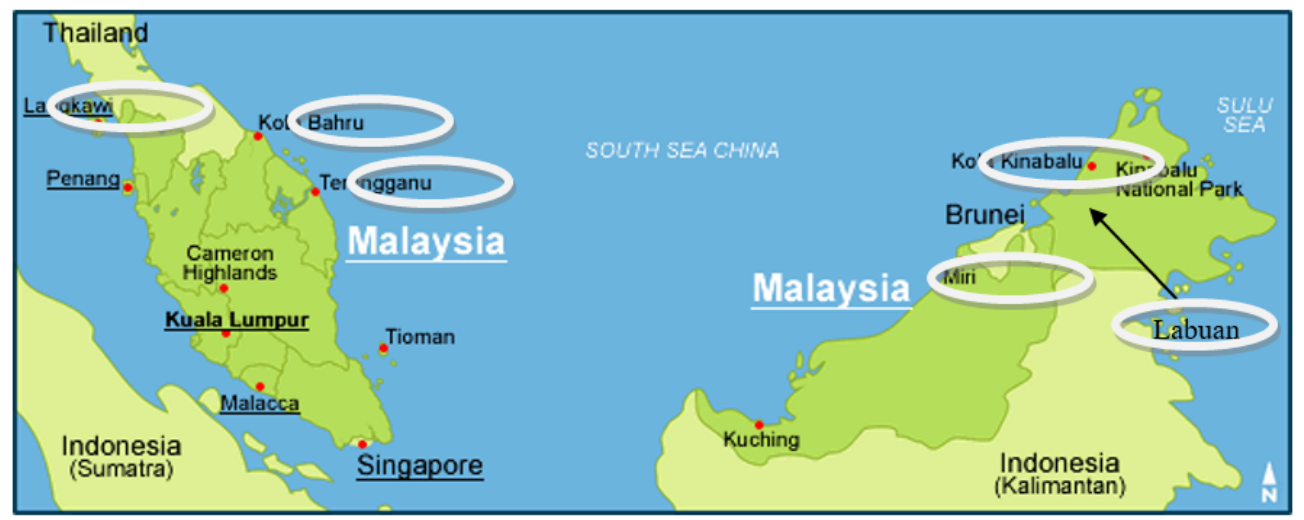

Figure 3. Map of target area

Table 3. List of target area and the specific position

\begin{tabular}{clll}
\hline No & Specific Location & \multicolumn{2}{c}{ Latitude/Longitude } \\
\hline i & Langkawi Island (North West Coast) & Latitude: 05 24N & Longitude: 103 06E \\
ii & Kota Bharu (East Coast) & Latitude: 06 10N & Longitude: 102 17E \\
iii & Kuala Terengganu (East Coast) & Latitude: 05 24N & Longitude: 103 06E \\
iv & Miri (West Borneo) & Latitude: 04 20N & Longitude: 113 59E \\
v & Victoria Labuan (East Borneo) & Latitude: 05 17N & Longitude: 115 14E \\
vi & Kota Kinabalu (North Borneo) & Latitude: 05 55N & Longitude: 116 03E \\
\hline
\end{tabular}

The next factor is the type of solar panel used. As indicated earlier in Section 2.2, the most effective technologies is the GaAs thin films which can achieve the module efficiency from $24.1 \%$ to $30.8 \%$. The extra benefits by choosing the GaAs is about the film thickness. It was found that the thickness is very thin and the structure is very flexible to ensure it could float on the water. The energy generated from the floating solar is calculated by using (1) [29].

$$
\mathrm{E}=\mathrm{H} \times \mathrm{r} \times \mathrm{A} \times \mathrm{PR}
$$

where $\mathrm{E}$ is energy $(\mathrm{kWh}), \mathrm{H}$ represents the yearly average solar irradiation measured on tilted panels (excluding shadings), $\mathrm{r}$ denotes the PV panel efficiency (i.e. GaAs 25\%), A is the effective solar panel area $\left(\mathrm{m}^{2}\right)$, and finally PR is the performance ratio or the coefficient for losses which ranges between 0.9 and 0.5 . In this case, the default value of 0.75 is taken. Example of losses that give the PR value (depend on the technology, the location of the installation and the sizing of the system) include temperature losses, inverter losses, DC and AC cables losses, shadings and losses due to panel covered with dust, snow, etc. and losses due to weak solar irradiation.

\section{RESULTS AND DISCUSSIONS}

The calculation of the annual energy generation by using the hexagon concept design installed in selected locations in Malaysia are then calculated. Figure 4 shows the annual energy yield from each location. Based on the result, using $25 \%$ of solar array efficiency, the annual maximum value recorded is $2592 \mathrm{MWh} /$ annum at Labuan and the minimum value recorded is $2285 \mathrm{MWh}$ /annum at Langkawi Island. 


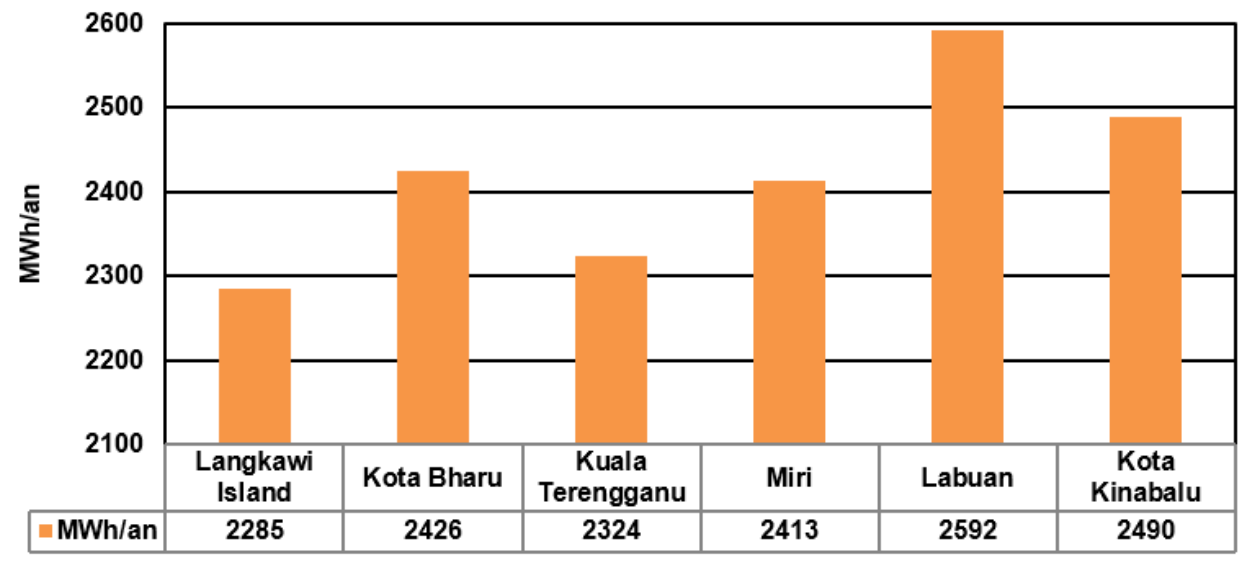

Figure 4. Annual energy yield of hexagon shape floating solar installed in selected installations in Malaysia

A similar analysis were carried out for circular shape floating solar. The result of energy generation shows that the highest energy will be generated in Labuan with the final value of $2241 \mathrm{MWh} / \mathrm{annum}$. However the lowest energy will be generated in Langkawi Island with a value of $1976 \mathrm{MWh} / \mathrm{annum}$. Therefore the selected design to deploy the floating solar is hexagonal prototype shape. From here, it can be concluded that the hexagon design offers a much higher energy yield.

\section{CONCLUSION}

The paper presents an analysis of floating solar technology. Floating solar has the potential to supply the energy need in many countries. Specifically for the analysis in this paper, it was predicted that 6 installations in selected locations in Malaysia has the capability to generate approximately around 14,530 MWh per annum. However, there are still a number of analysis needs to be carried out to ensure that such system could be implemented. This include analysis of possibly constructing the system into a large-scale concept with minimum maintenance. The ultimate criteria to be concerned are the safety factor and the structure should be environmental friendly. The physical structure of floating solar concept must also be a financially sustainable resolution. By doing this, floating solar could be one of the most important ocean structures in future because it is reliable, flexible and has virtually low cost of production when compared with other ocean structures.

\section{ACKNOWLEDGEMENTS}

The authors would like to thank Ministry of Higher Education (MOHE), Malaysia, Universiti Teknologi Malaysia (UTM) (Research cost centre no. R.K130000.7740.4J315 and Q.K130000.2540.16H95), the support of the Chilean Research Council (CONICYT), under the project Fondecyt 11160115 and School of Engineering, Robert Gordon University for funding this research project.

\section{REFERENCES}

[1] İ. Y1ldı, "1.12 Fossil Fuels," Compr. Energy Syst., pp. 521-567, Jan. 2018.

[2] F. Martins, C. Felgueiras, and M. Smitková, "Fossil fuel energy consumption in European countries," Energy Procedia, vol. 153, pp. 107-111, Oct. 2018.

[3] BP, "BP Statistical Review of World Energy," London, UK, 2017.

[4] R. A. Barreto, "Fossil fuels, alternative energy and economic growth," Econ. Model., vol. 75, pp. 196-220, 2018.

[5] M. E. Karim et al., "Energy revolution for our common future: An evaluation of the emerging international renewable energy law," Energies, vol. 11, no. 7, p. 1769:1-20, Jul. 2018.

[6] I. Berk, A. Kasman, and D. Kılınç, "Towards a common renewable future: The System-GMM approach to assess the convergence in renewable energy consumption of EU countries," Energy Econ., Feb. 2018.

[7] J. Li and C. Sun, "Towards a low carbon economy by removing fossil fuel subsidies?," China Econ. Rev., vol. 50, pp. 17-33, Aug. 2018.

[8] P. Moriarty and D. Honnery, "Can renewable energy power the future?," Energy Policy, vol. 93, pp. 3-7, 2016.

[9] T. Kåberger, "Progress of renewable electricity replacing fossil fuels," Glob. Energy Interconnect., vol. 1, no. 1, pp. 48-52, Jan. 2018. 
[10] REN21, "Renewables 2018 Global Status Report," Paris, France, 2018.

[11] IEA-PVPS, "Trends 2018 in Photovoltaic Applications," Switzerland, 2018.

[12] UN, "Factsheet: People and Oceans," in The Ocean Conference, 2017, pp. 1-7.

[13] C. M. Wang and Z. Y. Tay, "Very Large Floating Structures: Applications, Research and Development," Procedia Eng., vol. 14, pp. 62-72, Jan. 2011.

[14] T. Choisnet, S. Vasseur, S. Marobin, E. Rogier, M. Favre, and B. Dumad, "Report on the Requirements of the Floating Structure," 2013.

[15] U. Waheed, "Floating Leisure's: A Luxury Holiday Resorts," Punjab University College of Arts and Design, 2013.

[16] A. Andrianov, "Hydroelastic Analysis of Very Large Floating Structures," Dnepropetrovsk Nationale Universiteit, Oekraine, 2005.

[17] B. D. Naji Tahan, "Offshore Installation," Handb. Offshore Eng., pp. 1055-1126, Jan. 2005.

[18] C. Capanoglu, "Novel and Marginal Field Offshore Structures," Handb. Offshore Eng., pp. 39-77, Jan. 2005.

[19] M. Rosa-Clot, G. M. Tina, M. Rosa-Clot, and G. M. Tina, "The Floating PV Plant," Submerg. Float. Photovolt. Syst., pp. 89-136, Jan. 2018.

[20] M. Rosa-Clot, G. M. Tina, M. Rosa-Clot, and G. M. Tina, "Floating Plants and Environmental Aspects," Submerg. Float. Photovolt. Syst., pp. 185-212, Jan. 2018.

[21] K. Trapani, D. L. Millar, and H. C. M. Smith, "Novel offshore application of photovoltaics in comparison to conventional marine renewable energy technologies," Renew. Energy, vol. 50, pp. 879-888, Feb. 2013.

[22] L. Smadja and P. I. Smadja, "Floating Solar Panel System," 20160156304, 02-Jun-2016.

[23] M. R. Pinto, "Has the sun finally risen on photovoltaics?," in Symposium on VLSI Technology, 2008, pp. 2-5.

[24] T. M. Razykov, C. S. Ferekides, D. Morel, E. Stefanakos, H. S. Ullal, and H. M. Upadhyaya, "Solar photovoltaic electricity: Current status and future prospects," Sol. Energy, vol. 85, no. 8, pp. 1580-1608, Aug. 2011.

[25] R. W. Miles, K. M. Hynes, and I. Forbes, "Photovoltaic solar cells: An overview of state-of-the-art cell development and environmental issues," Prog. Cryst. Growth Charact. Mater., vol. 51, no. 1-3, pp. 1-42, Jan. 2005.

[26] M. A. Green, K. Emery, Y. Hishikawa, W. Warta, and E. D. Dunlop, "Solar cell efficiency tables (version 39)," Prog. Photovoltaics Res. Appl., vol. 20, no. 1, pp. 12-20, Jan. 2012.

[27] S. H. Abu-Bakar, "Novel Rotationally Asymmetrical Solar Concentrator for the Building Integrated Photovoltaic System," PhD Thesis, Glasgow Caledonian University, United Kingdom, 2016.

[28] J. Taverne et al., "Solar powered charging backpack," in International Conference on Electrical, Electronic, Communication and Control Engineering (ICEECC2017), 2017, pp. 1-8.

[29] Photovoltaic Software, "How to calculate output energy of PV solar systems?," 2019. [Online]. Available: https://photovoltaic-software.com/principle-ressources/how-calculate-solar-energy-power-pv-systems. [Accessed: 26-Mar-2019]. 